\title{
Gingivostomatitis herpetik primer pada anak Primary herpetic gingivostomatitis on children
}

\author{
${ }^{1}$ Astrid Palmasari, ${ }^{2}$ M. Jusri \\ ${ }^{1}$ Residen Program Pendidikan Dokter Spesialis Prodi Oral Medicine \\ ${ }^{2}$ Departemen Oral Medicine \\ Fakultas Kedokteran Gigi Universitas Airlangga \\ Surabaya, Indonesia
}

\section{ABSTRACT}

Herpetic gingivostomatitis is an infection of primary herpes simplex virus (HSV) type-1 characterized by vesiculoulcerative lesion. This diseasae commonly seen in 1 until 5-year-old children, but occur in adult occasionally. This paper reports a 5-year-old girl with chief complaint ulcerations in oral cavity. Fever and malaise proceed ulcers five days before. The diagnosis primary herpetic gingivostomatitis was based on this first and many ulcers. Antivirus agent, multivitamin, benzydamine $\mathrm{HCl}$ gargle and high calorie and high protein diet was given to the patient. Herpetic gingivostomatitis usually healed by time, but recurrent herpes simplex virus can avoid with proper therapy and monitoring.

Key words: primary herpetic gingivostomatitis, herpes simplex virus, acyclovir

\begin{abstract}
ABSTRAK
Gingivostomatitis herpetik merupakan infeksi primer dari virus herpes simplek (VHS) tipe 1 dengan karakteristik berupa lesi vesikuloulseratif. Penyakit ini biasanya diderita oleh anak berusia 1-5 tahun. Meskipun jarang, pada beberapa kasus juga ditemukan pada orang dewasa. Di dalam artikel ini dibahas tentang tatalaksana penanganan gingivostomatitis herpetik primer pada anak perempuan berusia 5 tahun dengan keluhan banyak sariawan mulutnya, yang 5 hari sebelumnya mengeluh meriang, dan demam. Berdasarkan anamnesis dan pemeriksaan klinis, diagnosis klinis ditentukan sebagai gingivostomatitis herpetik primer. Terapi yang dilakukan adalah pemberian antivirus (acyclovir), multivitamin, obat kumur benzydamine HCL dan diet tinggi kalori dan protein. Sebagai simpulan, diagnosis gingivostomatitis herpetik dapat ditegakkan dengan melakukan anamnesis dan pemeriksaan klinis secara teliti. Melalui terapi dan pengawasan yang adekuat, proses penyembuhan dapat dipercepat dan risiko infeksi sekunder dari VHS dapat dicegah.
\end{abstract}

Kata kunci: gingivostomatitis herpetik primer, virus herpes simplek, acyclovir

Koresponden: Astrid Palmasari, Fakultas Kedokteran Gigi Universitas Hang Tuah, Jl. Arief Rahman Hakim No.150 Surabaya, Indonesia.E-mail: pastrid81@yahoo.com 